\title{
ASSESSING THE DEVELOPMENT POTENTIAL OF MODERN RETAIL IN VIETNAM
}

\author{
Tran Tuan Anh \\ Ho Chi Minh City Open University \\ Email: tuananhdhm@yahoo.com \\ (Received: 04/04/2015; Revised: 06/05/2015; Accepted: 19/05/2015)
}

\begin{abstract}
Vietnam retail market is one among the attractive retail markets in the world. The development of retail market leads to the formation and development of modern retail formats. Currently, the modern retail formats like supermarkets, commercial centers, convenience stores are gradually replacing the traditional forms of retail stores such as markets and individual business. This study was conducted to assess the development potential of modern retail in Vietnam. The foundation of this development is the growth of the size of the domestic retail market, the increasing degree of urbanization and the rapid increase of foreign investment projects in the retail sector, thanks to Vietnam's economic progress of integration with the world economy. The study results showed that after about the first 20 years of formation and development, the modern retail formats are entering the stage with strong development potential.
\end{abstract}

Keywords: retail market, modern retail, Vietnam.

\section{Introduction}

Vietnam retail market is one among those with high growth rates in the ASEAN region. In the period of 1995 - 2014, the average growth rate of Vietnam's retail market is maintained for about $15 \%$ per year. This is an impressive figure compared with the average retail market growth rate of other ASEAN countries. Besides high growth rate, Vietnam's retail market reached a large scale thanks to the population of about 90 million people. On average, Vietnam's population increased by about 1 million people every year. Stable population growth guarantees for the development of scale of the retail market in Vietnam. Moreover, Vietnam's population is of young structure that has more than two thirds of the population in working age. This is a dynamic consumer group, with high consuming demand, having a positive effect on the development of the retail market.

The process of socio-economic development of Vietnam is promoting the process of urbanization in the country. The level of urbanization in Vietnam increased gradually every year. The inhabitants moved to urban areas progressively. Urbanization process increases the number of urban centers. In big cities like Hanoi and Hochiminh city, population is more and more increasing. The transformation of urbanization creates conditions for the development of modern retail formats.

Since 2007, Vietnam has officially become a member of the World Trade Organization (WTO). In fact, after joining the WTO, the flow of foreign direct investment in Vietnam has increased. Vietnam has the opportunity to receive more investment projects in various economic sectors, including retail market. Policies to attract foreign direct investment by the government have created many opportunities for professional retailers in the world to penetrate the retail market in Vietnam. Many investment projects in developing supermarket chains, commercial centers, and convenience stores have been deployed with increasing scales. This 
investment wave has promoted to change the face of retail market of Vietnam. Previously, retail format in Vietnam was mainly traditional ones including markets and shops, but now, modern retail formats are gradually formed and developed.

\section{Growth of retail market size}

The Vietnam retail market is evaluated as one among the attractive retail markets in the world. According to AT Kearney's research, in 2014, Vietnam's retail market ranked 28th in the top 30 attractive retail markets. According to this study, the GRDI (Global Retail Development Index) of Vietnam reached 39.1 and was in the top four countries in the ASEAN region (including Malaysia, Indonesia, Philippines, and Vietnam) which had attractive retail markets in the world. One of the attractive features of
Vietnam's retail market was the growth in size of the retail market. Compared with 2004, the retail market size in 2014 increased more than 7 times (Figure 1). The average growth rate of retail market size in this period reached $18.6 \%$ per year. This is an impressive growth rate if compared with the average growth rate of the retail market in the ASEAN region.

The Vietnam retail market size is demonstrated by the total retail sales of goods. According to the General Statistics Office of Vietnam, the total retail sales of goods is an indicator used to reflect sales of goods from enterprises and production and business establishments, through a network of different types of retail, directly to individuals and households for consumption purposes. Total retail sales of goods reflects the consumption of individuals and families in Vietnam.

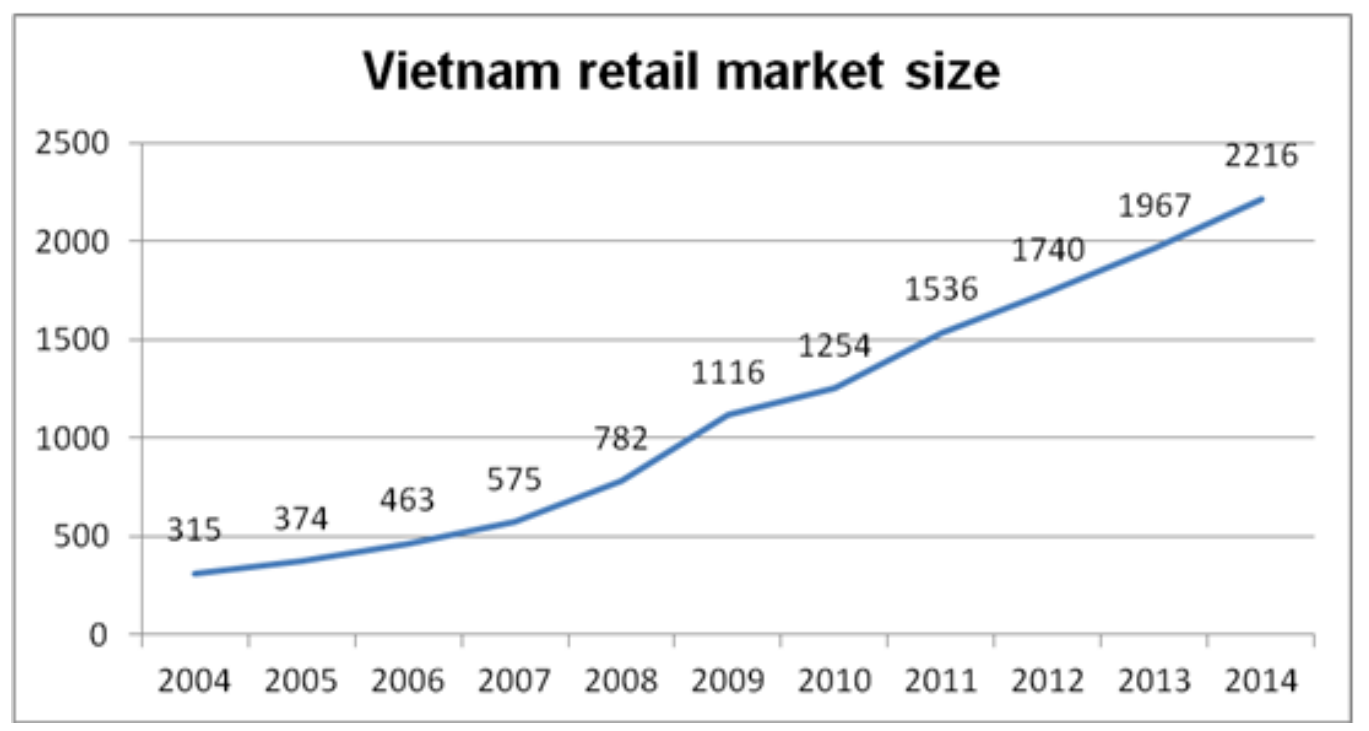

Figure 1. Vietnam retail market size over the period $2004-2014$

Source: Vietnam General Statistics Office

How much the growth of Vietnam retail market size will be in the coming years? Some forecasting models can be used to forecast the growth of the retail market. According to (Goodness, 2013), ARIMA model is more suitable to forecast the growth of retail market than other univariate forecasting methods. ARIMA model is a combination of auto regressive models (AR), moving average model (MA) and integrated time series. One of the outstanding features of the ARIMA model is to be able to transform to stationary time series from nonstationary time series by differencing method. A nonstationary time series, meaning not having the form of integrated of order zero, can become stationary in the form of integrated of order d. According to ARIMA method, all stationary time series can be expressed as auto regressive and moving average combination. In notation ARIMA (p, d, q), p is the degree of auto regressive model $\operatorname{AR}(p), q$ is the order of the 
moving average model $\mathrm{MA}(\mathrm{q})$ and $\mathrm{d}$ is the order of integrated time series I(d). The Box Jenkins procedure is regularly used to set up and test the model before applying that model to forecast.

The general form of ARIMA:

$$
\begin{aligned}
& \quad\left(1-\phi_{1} B-\cdots-\phi_{p} B^{p}\right)(1-B)^{d} y_{t} \\
& =c+\left(1+\theta_{1} B+\cdots+\theta_{q} B^{q}\right) e_{t} \\
& \text { where: } \mathrm{p}=\text { order of auto regressive. }
\end{aligned}
$$

$$
\begin{aligned}
& \mathrm{q}=\text { order of moving average } \\
& \mathrm{d}=\text { order of integrated time series. } \\
& \mathrm{B}=\text { lag operator. } \\
& y_{t}=\text { time series. } \\
& e_{t}=\text { white noise. }
\end{aligned}
$$

To estimate ARIMA models, R software and two functions named auto.arima() and Arima() were used. The results are showed in table 1.

Table 1. Results of estimating ARIMA models

\begin{tabular}{|l|c|c|c|c|c|c|}
\hline Models & AR() & MA() & Log LL & AIC & AICc & BIC \\
\hline ARIMA(1.2.0) & -0.5153 & & -124.51 & 253.03 & 253.63 & 255.3 \\
\hline ARIMA(0,2,1) & & -0.4097 & -125.39 & 254.79 & 255.39 & 257.06 \\
\hline ARIMA(1,2,1) & -0.4661 & -0.0704 & -124.49 & 254.97 & 256.23 & 258.38 \\
\hline ARIMA(2,2,0) & -0.5519 & -0.0652 & -124.46 & 254.93 & 256.19 & 258.33 \\
\hline
\end{tabular}

Source: Data analysis using $R$ software.

Where: $\operatorname{AR}()$ column $=$ auto regressive coefficient.

MA () column = moving average coefficient.

Log LL $=\log$ likelihood value of the data. This value is the logarithm of the probability of the observed data obtained from the model estimates. For the value of p, q, and $\mathrm{d}$ of the model, $\mathrm{R}$ maximizes $\log \mathrm{LL}$ value to find out the estimated parameters.

$\mathrm{AIC}=$ Akaike Information Criterion.

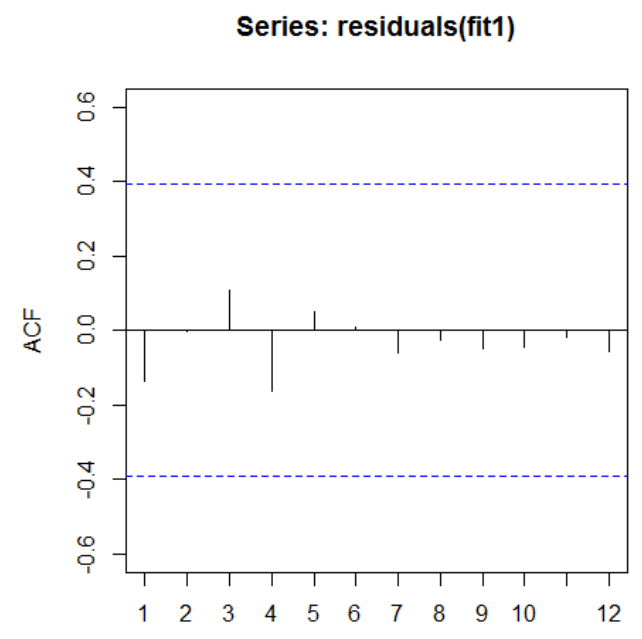

Lag

Figure 2. plots of ACF and PACF of residuals from the model ARIMA $(1,2,0)$

$\mathrm{AIC}_{\mathrm{c}}=$ "biased - Corrected" Akaike Information Criterion.

BIC = Bayesian Information Criterion.

From the results of data analysis using $\mathrm{R}$, and the $\mathrm{AIC}, \mathrm{AIC}_{\mathrm{C}}$ and $\mathrm{BIC}$ criterion, the model ARIMA $(1,2,0)$ is found suitable for applying forecast.

ACF (autocorrelation function) and PACF (partial autocorrelation function) of residuals from ARIMA $(1,2,0)$ estimation are showed in figure 2 .

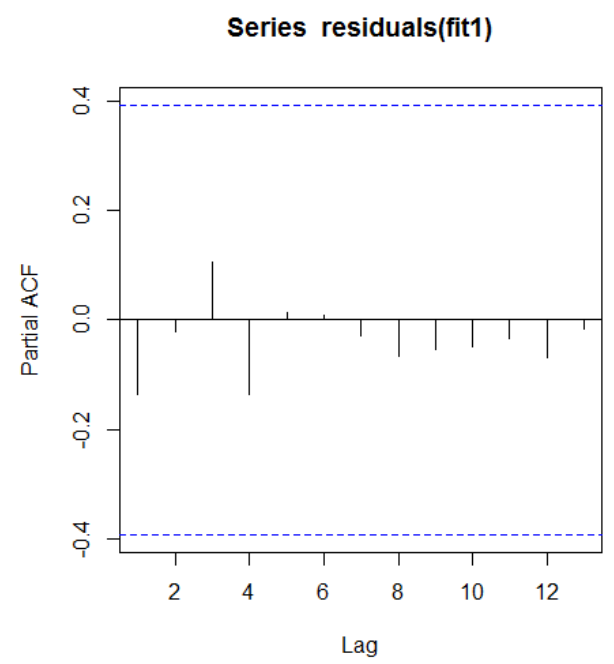

Source: Data analysis using $R$ software. 
Figure 2 shows the residuals from the model ARIMA $(1,2,0)$ with correlations within the threshold limits, ie the residual is a white noise.

Performing Ljung - Box test for the residuals of the model ARIMA $(1,2,0)$ by $R$ with hypotheses:

$\mathrm{H}_{0}$ : residuals from the model ARIMA $(1,2,0)$ is a white noise.

$\mathrm{H}_{1}$ : residuals from the model ARIMA $(1,2,0)$ is not a white noise.

The level of significance of the test is 0.05 .

We have the following results:

$\chi^{2}=0.458$ and $\mathrm{p}$ value $=0.4956$.
The $p$ value is the smallest level of significance at which $\mathrm{H}_{0}$ can be rejected. In this case, the null hypothesis is not rejected because the $p$ value $(0.4956)$ is bigger than the level of significance of the test (0.05). From the test results, it could be concluded that the remainder of the models has the form of a white noise. Therefore, ARIMA model $(1,2,0)$ conform to forecast the growth of Vietnam retail market size.

Applying the ARIMA model $(1,2,0)$ to the forecast, we have predicted the Vietnam retail market size during the period 2015 2020 with a $95 \%$ confidence level as follows:

Table 2. Forecast results, point and interval estimation.

\begin{tabular}{|l|c|c|c|c|c|c|}
\hline Year & 2015 & 2016 & 2017 & 2018 & 2019 & 2020 \\
\hline Point estimation & 2453.5 & 2696.9 & 2937.2 & 3179.2 & 3420.4 & 3661.9 \\
\hline Lo 95 & 2347.7 & 2507.6 & 2634.5 & 2752.2 & 2853.0 & 2942.8 \\
\hline Hi 95 & 2559.2 & 2886.2 & 3240.1 & 3606.3 & 3987.7 & 4381.1 \\
\hline
\end{tabular}

Lo $95=$ lower limit of the forecast with a $95 \%$ confidence level.

Hi $95=$ upper limit of the forecast with a 95\% confidence level.

Source: Data analysis using $R$ software.

Forecasts from ARIMA(1,2,0)

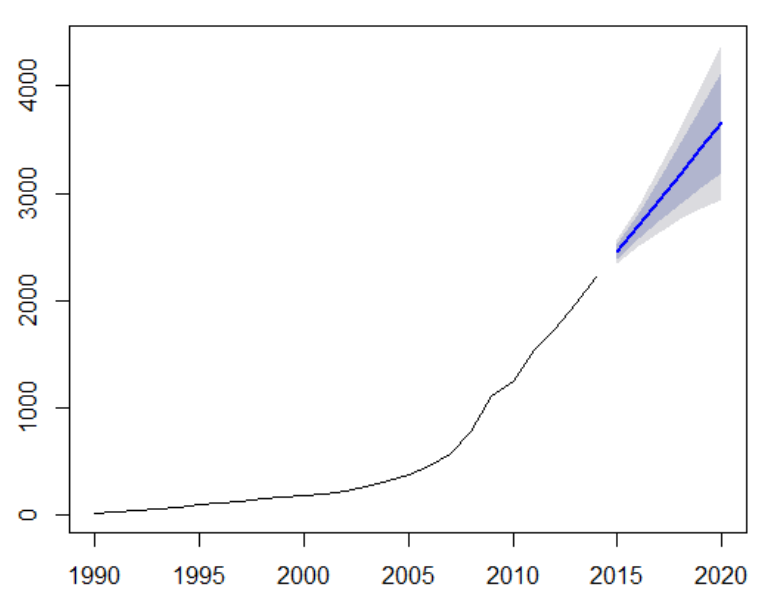

Figure 3. Forecast Vietnam retail market size from ARIMA $(1,2,0)$

Source: Data analysis using $R$ software.

According to studies from the retail markets in India, China and Thailand, the size of the retail market is one of the important factors to attract foreign investors, especially worldwide giants as Walmart, Tesco PLC,
Carrefour SA.

\section{Urbanization rate}

In the early 1990s, those first supermarkets putting into operation in Ho Chi Minh City created a turning point in the formation and development of modern retail in Vietnam. Until today, there have been many modern retail formats arriving in Vietnam but the most common ones are supermarkets, hypermarkets, commercial centers, convenience stores, and online retailers. Similar to other countries, in the early stages of the development process, the modern retail format in Vietnam grew mainly in urban centers. Practical researches showed that the development of different types of retail in Vietnam has grown up together with urbanization process. Supermarket chains, shopping centers, convenience store chains began to form and grow mainly in urban areas, especially in Hanoi and Ho Chi Minh City and then have spread to other urban centers in the country. 
Urbanization is the process of urban development in a country. It reflects population flows from rural to urban areas. More people living in cities increased urbanization status. Consequently, the proportion of urban population against the total population is often used to measure the degree of urbanization. According to the Urban Planning Law, the urban population is the population of the administrative boundary of the municipality, including urban, suburban, and township.

Urban center is an area with a dense population mainly engaged in non-agricultural economic activities, which is a political, administrative, economic, cultural or specialized center playing the role of promoting the socio-economic development of a country, a territorial region or a locality, and consists of inner city and suburbs, for a city; inner town and outskirts, for a town; and townships (law on urban planning, 2009). According to the classification of the state through decree 42/2009 ND-CP, dated $7 / 5 / 2009$, urban centers in Vietnam are classified into 6 grades: special grade and grades I, II, III, IV and $\mathrm{V}$ according to location, function, role, structure and socioeconomic development level of urban centers, population size, population density, nonagricultural labor proportion and infrastructure development level. Special grade urban centers are managed directly under the central government, with urban centers affiliated with the urban districts and suburban districts. In Vietnam, there are two special grade urban towns that are Hanoi and Ho Chi Minh City.

In Vietnam, the process of urbanization took place accompanying the process of social-economic development in the country. However, since the early 1990s, the process of urbanization has begun to occur more rapidly than that in earlier stages. During the 1970s and 1980s, the level of urbanization was relatively stable at the rate of urban population against total population approximately $19 \%$. But since the 1990s, this rate tended to rise and the growth rate has been gradually increased annually. If in the period $1991-1995$, the proportion of urban dwellers in Vietnam was approximately $20 \%$, then in 2013, this rate reached $32.2 \%$ (see Figure 4 ).

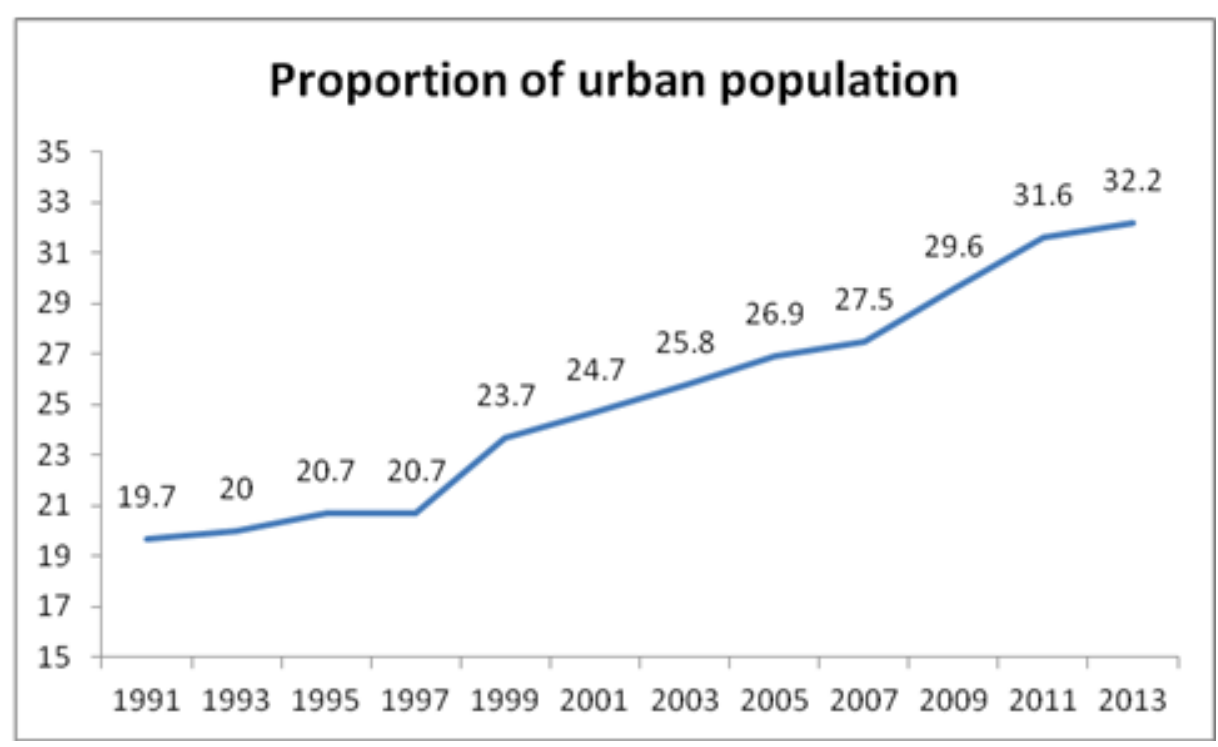

Figure 4. Percentage of urban population to total population for the period 1991-2013

Source: Vietnam General Statistics Office

In parallel with the degree of urbanization, municipalities in Vietnam have increased rapidly in number and quality. If in
Unit: percent

1990, Vietnam has got 500 cities, then, according to the urban development plan of Vietnam government, until 2015, the whole 
country will have 870 cities, increasing $74 \%$ in 15 years. According to the urban classification of the government, in the total of 870 cities in Vietnam, there are 2 special grade municipalities that are Hanoi and Ho Chi Minh City, 9 grade I municipalities, 23 grade II, 65 grade III, 79 grade IV and 687 grade V municipalities. Based on the number of people living in cities, Vietnam has 2 municipalities with more than 2 million inhabitants, 4 cities with population size from 500 thousand to 2 million people and 9 cities with population size from 200 thousand to 500 thousand people. It is practically proved that the modern retail forms including commercial centers, supermarkets, hypermarkets, convenience stores thrive in this urban group.

Table 3. Municipalities with more than 200,000 people

\begin{tabular}{|l|c|l|}
\hline \multicolumn{1}{|c|}{ Population } & Number & \multicolumn{1}{|c|}{ Urban } \\
\hline Over 2 million people & 2 & Hanoi, Ho Chi Minh city. \\
\hline $\begin{array}{l}\text { From 500 thousand to } 2 \\
\text { million people }\end{array}$ & 4 & Hai Phong, Da Nang, Can Tho, Bien Hoa. \\
\hline $\begin{array}{l}\text { From 200 thousand to } \\
500 \text { thousand people }\end{array}$ & 9 & $\begin{array}{l}\text { Nha Trang, Vung Tau, Hue, Quy Nhon, Vinh, Buon Me } \\
\text { Thuoc, Ha Long, Long Xuyen, Rach Gia. }\end{array}$ \\
\hline
\end{tabular}

Source: Vietnam General Statistics Office, 2009

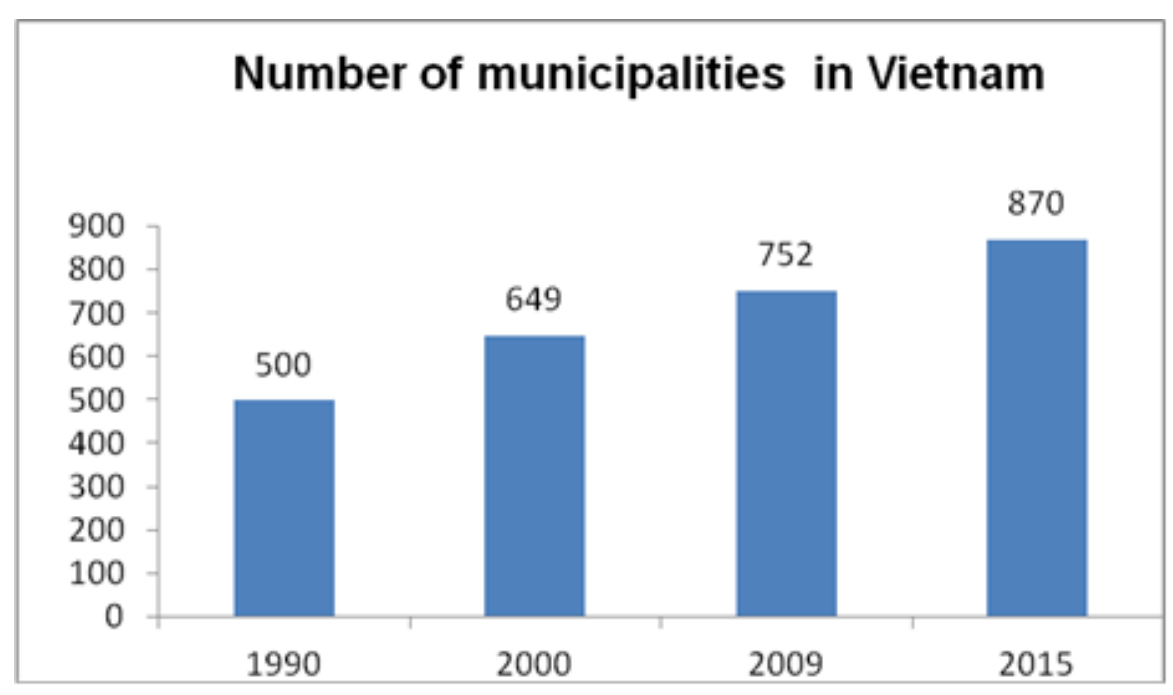

Figure 5. Number of municipalities in Vietnam for the period 1990-2015

Source: Vietnam General Statistics Office, Vietnam Urban Planning and Development Association.

Among municipalities in Vietnam, Ho Chi Minh City and Hanoi are the two that have the highest growth rate of commercial centers, supermarkets, hypermarkets, convenience stores. Most of the major supermarket chains, commercial centers, convenience store chains are formed and strongly developed in these cities before spreading to other cities. For example, the original supermarket Co.opmart, Big C, Metro, Lotte Mart, the original commercial center of Parson, the initial convenience store of Family Mart, Circle K, Shop \& Go were established in Ho Chi Minh City and Hanoi earlier than in other cities. In 2013, the first hypermarket in Vietnam, ventured between Saigon Co.op and NTUC Fair Price (Singapore), also opened in Ho Chi Minh City. Obviously, the process of urbanization has created the infrastructure for the formation and development of modern 
retail formats in Vietnam.

\section{Foreign Direct Investment}

Foreign direct investment has played an important role in the economic development process in Vietnam. Inflow of foreign direct investment has contributed to the growth of investment capital for economic development in the country. Capital ratio of foreign direct investment in total investment has increased annually. In the period 2001 - 2006, foreign direct investment capital accounted for $16 \%$ of total social investment capital. Then in the period 2007 - 2014, this ratio had increased and accounted for approximately 30\%. This capital source became an important factor for economic development in the country. In the last 5 years, the amount of implemented capital from foreign direct investment has averaged about 10 - 12 billion USD per year. In addition to the capital, foreign direct investment has also transferred technology to
Vietnam, helping to create jobs for the domestic labor force. This technological factor has contributed to improve the level of technology in the country and raise labor productivity of the workforce. Increasing labor productivity is the basis for raising the income of workers and improving the quality of life of people in the country.

In the retail sector, flow of capital and technology through foreign investors has contributed to promoting changes of domestic retail service towards modernization. Most of the investment projects in the retail sector have focused on the modern retail formats such as hypermarkets, supermarkets, commercial centers, convenience stores. Until 2014, the foreign direct investment supermarkets have accounted for $40 \%$ of total supermarket in the country (Association of Vietnam Retailers, 2014).

Table 4. Some big FDI projects in the retail market in Vietnam

\begin{tabular}{|l|l|l|l|}
\hline \multicolumn{1}{|c|}{ Project } & \multicolumn{1}{c|}{ Business } & \multicolumn{1}{c|}{ Year } & \multicolumn{1}{c|}{ Quantity } \\
\hline Big C supermarket chain & Casino, France & 1998 & 26 supermarkets \\
\hline Metro cash\&carry supermarket chain & Metro, Germany & 2002 & 19 supermarkets \\
\hline Parkson commercial center chain & Lion, Malaysia & 2005 & 8 commercial centers \\
\hline Shop \& Go convenience shop chain & Shop\&Go Vietnam & 2005 & 125 shops \\
\hline Lotte mart supermarket chain & Lotte, Korea & 2008 & 7 supermarket \\
\hline Circle K convenience shop chain & Circle K Vietnam & 2008 & 100 shops \\
\hline Aoen commercial center & Aoen, Japan & 2011 & 2 commercial centers \\
\hline Co.op Extra hypermarket chain & NTUC Fair Price, Singapore & 2013 & 2 hypermarkets \\
\hline Family mart convenience shop chain & Family mart, Japan & 2013 & 63 shops \\
\hline Bmart convenience shop chain & ThaiBerli Jucker Plc, Thailand & 2013 & 75 shops \\
\hline
\end{tabular}

Source: Compiled from information of companies.

The process of opening up the retail market in Vietnam creates favorable conditions for foreign investors to boost investment in the retail sector. If in the period 2007 - 2009, foreign investors who wanted to implement investment projects in Vietnam had to have joint ventures with local firms with capital ratios below 50\%. Since 2009, enterprises with $100 \%$ foreign capital have been permitted to establish and open retail outlets in Vietnam. The process to establish affiliates should satisfy the economic needs test (ENT) which was evaluated by local government and ministry of industry and trade. The main criteria for the test are: the number of retail service providers located in a geographical area, the stability of market and geographic scale. In recent years, besides the 
form of investment in the retail market through joint ventures with local firms, many foreign investors have chosen merger and acquisition form ( $M \& A)$ to expand investment projects. For example, in 2014, ThaiBerli Jucker Plc from Thailand bought Metro Cash \& Carry supermarket chain. Buy Power owns 49\% shares of the Nguyen Kim supermarket chain, one of the top ten retailers in Vietnam. Aeon, a Japanese retail giant bought a $30 \%$ shares in Fivimart supermarket chain and $49 \%$ shares in Citimart supermarket chain. Fivimart supermarket chain has 18 supermarkets in Hanoi; and Citimart supermarket chain includes of 28 supermarkets in big cities of Vietnam. Thus, besides investment form such as joint venture or $100 \%$ foreign capital enterprise, the form of $M \& A$ has promoted the integration of the foreign direct investment into the retail market in Vietnam.

5. Development potential of modern retail

As in the early stage of development, market share of goods sold through supermarkets, hypermarkets, commercial centers, convenience stores, specialized stores in Vietnam is still low. According to the research by Nielsel, market share of goods sold to consumers through modern retailers in Vietnam accounted for $13 \%$ (Nielsen, 2011). Comparing with the market share of modern retail of countries in the ASEAN region and in the world, the modern retail market in Vietnam is quite low.

In Thailand, the market share of modern retail accounts for $43 \%$. In Singapore, this value is about $71 \%$. The market share of modern retail in developed countries typically accounts for about $70-80 \%$ of the domestic market. According to forecasts of experts in retail sector, the market share of modern retail market in Vietnam will reach $40 \%$ by 2020 (Association of Vietnam Retailers, 2014).

The opportunities of developing modern retail in Vietnam remain high thanks to the government's supported policies to the retail market development. According to the plan for developing supermarket and trade centers network in Vietnam until 2020 of the Ministry of Industry and Trade, the perspective of modernization domestic retail system was expressed by the planning to increase the modern retail facilities in the country. According to this plan, by 2020, the number of supermarkets in the country is expected to be around 1200 to 1300 , the number of commercial centers is expected at about 180 (Ministry of Industry and Trade, 2012).

The size of the retail market in Vietnam will have high growth rates and forecasted to reach 3661 trillion VND in 2020. In compare with 2014, the size of Vietnam retail market in 2020 will increase about threefold. The big retail market size will impact positively on the growth of modern retail system.

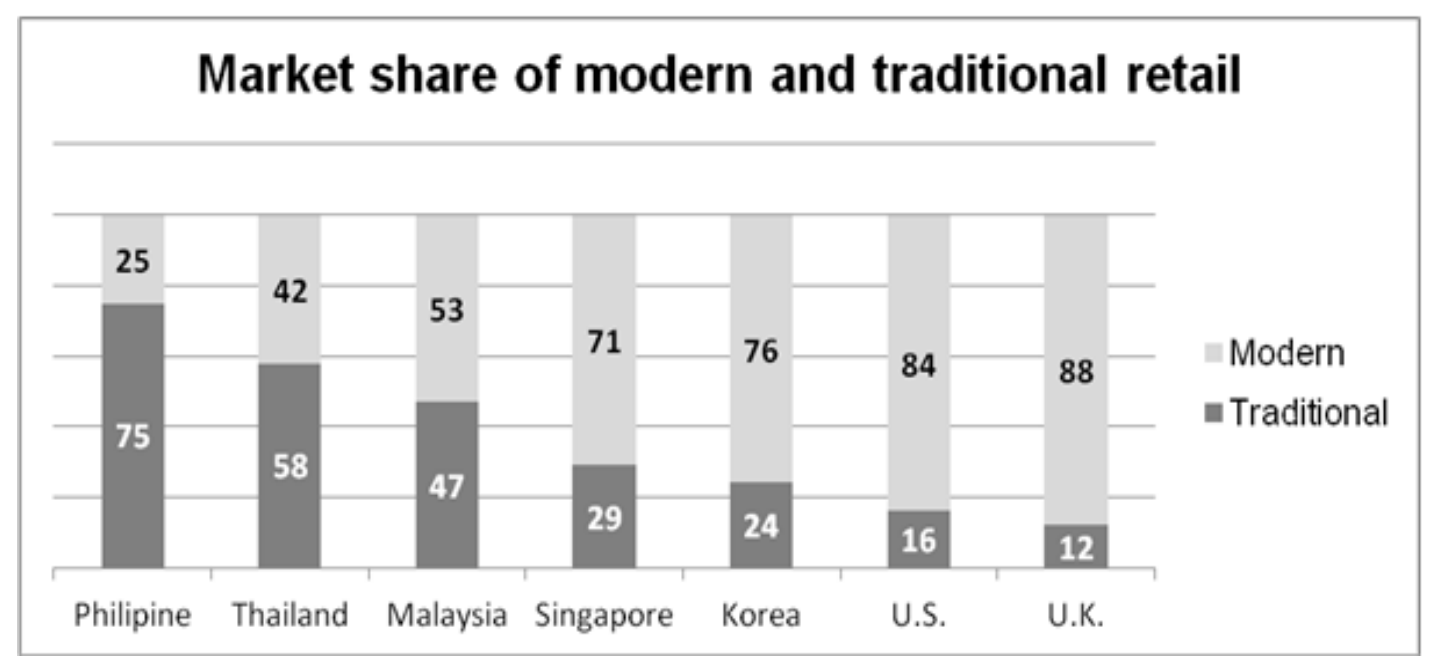

Figure 6. Market Share of modern retail and traditional retail in some ASEAN countries and in the world 
According to the rules of developing of modern retail in the world, the process of formation and development took place initially in urban areas, especially in large cities of the country and then spread to other city towns. The process of urbanization in Vietnam has been happening with a high rate. According to Vietnam General Statistics Office, until 2020, Vietnam's population will reach about 100 million people, of which the proportion of urban population is about $40 \%$ (GSO, 2010). In addition, urban network in the country will be upgraded in quality and be increased in quantity. According to the master plans of urban development system oriented by the government, until 2025, the number of municipalities in Vietnam will be 1000, in which, there are 2 special municipalities, 15 grade I municipalities, 20 grade II, 81 grade III, 122 grade IV and the remaining belonged grade V urban (445/QD-TTg). The urban system has been developing in Vietnam that creates opportunities for the growth of modern retail. According to the roadmap for executing the commitments of economic integration in the world, conditions for inflows of foreign direct investment in the domestic retail market have been becoming more favorable. In late 2015, the ASEAN Economic Community (AEC) will be officially established. This event will increase the interoperability of Vietnam retail market and create opportunities for foreign investors to expand their network of retail establishments. The development of forms of M\&A among enterprises in the ASEAN economic community will contribute to the increase of investment flow into Vietnam retail market.

\section{Conclusion}

Modernization of retail distribution network in Vietnam is consistent with the law of economic and social development process. Since the period of economic transformation and integration into the world economy, the retail market in Vietnam has grown rapidly. The modern retail forms are shaped and developed in the context of the retail market growing rapidly in size. In the past twenty years, modern retail network in Vietnam was formed and flourished. Commercial centers, supermarkets, hypermarkets, convenience stores and specialized stores are gradually replacing the wet markets and the small stores.

In the coming years, the modern retail formats have strong development potential. The solid foundation for this growth is the size of the retail market in Vietnam. The size of the retail market in Vietnam will grow with high rate thanks to favorable basis of economic growth and large population. High urbanization rate in Vietnam will facilitate the development of modern retail formats. The level of urbanization is increasing along with the development of the urban network in Vietnam creating the basis for the growth of modern retail formats such as commercial centers, supermarkets, hypermarkets, convenience stores. It is obviously seen that in the two special large cities, Hanoi and Ho Chi Minh, the modern retail forms thrive and have the big growth potential. The process of modernization of the distribution system in Vietnam needs more capital and technologies. While domestic resources are limited, inflow of foreign direct investment has provided capital and technology for modern retail in the country. According to the process of integration to world economy and ASEAN economic community, foreign investors gain more favorable conditions for deployment and expansion of their projects in the Vietnam retail market. This investment stream is so essential to the growth of modern retail to keep up with the development trend of the retail market of the world.

\section{REFERENCES}

ADB, (2015), ASEAN Development Outlook 2015 Report. Philippines: Asian Development Bank.

Association of Vietnam Retailers. (2011). Overview: Vietnam retail distribution network. Hanoi: Association of Vietnam Retailers. 
Association of Vietnam Retailers. (2014). International experience of the retail distribution network. Hanoi: Association of Vietnam Retailers

Center for Information of Industry and Commerce, Ministry of Industry and Trade. (2010). Domestic market - potential still open. Hanoi: Industry and Trade publisher.

Center for Information of Industry and Commerce, Ministry of Industry and Trade. (2010). Promoting trade and domestic demand, situation and solutions. Hanoi: Industry and Trade publisher.

Congress. (2009). Law on urban planning, No. 30/2009/QH12, date 17/06/2009.

Damodar, N. G., Dawn C. P. (2009), Basic Econometrics. NY: Mc Graw - Hill.

Euromonitor. (2013). Indonesia Retailers: Organizing the shelf, filling the shopping basket. Indonesia: Euromonitor.

General Statistics Office. (2013), Statistical Yearbook. Hanoi: Statistics publisher.

Goodness, C., Mehmet, B., Ragan, G., Anandamayee, M. (2013), Forecasting Aggregate Retail Sales: The Case of South Africa, Department of Economics, University of Pretoria.

Goodness, C., Mehmet, B., Ragan, G., Anandamayee, M. (2013), Forecasting Aggregate Retail Sales: The Case of South Africa, Department of Economics, University of Pretoria.

Kearney,A. T. (2011). Expanding opportunities for global retailers, Chicago: A.T. Kearney.

Kohli, R. (2011), Organized Retailling in India: Issue and outlook, Columbia University, retrieved from http://ssrn.com/abstract=2049901.

Ministry of Industry and Trade. (2012). Approval planning for network development of supermarkets, commercial centers throughout the country until 2020 and vision for 2030. Decision No 6184/QĐ-BCT, date 19/10/2012.

Neilsen. (2011). The report on retail sales in Vietnam, Hanoi: The Neilsen company.

Nguyen Thi Dieu Chi, (2010), Retail distribution system of Vietnam goods in the international economic integration progress. Journal of Information and Economic Forecast, No54.

Prime Minister. (2009). Decision on approving master plan for Vietnam's urban system in 2015 with a vision to 2015. Decision No 445/QD-TTg, date 07/04/2009.

Satyajit, R. (2010), Foreign Direct Investment in Retial Market in Indian: Some Issues and Challenges, ResearchJournali's Journal of Economics, ISSN 2347-8233. 